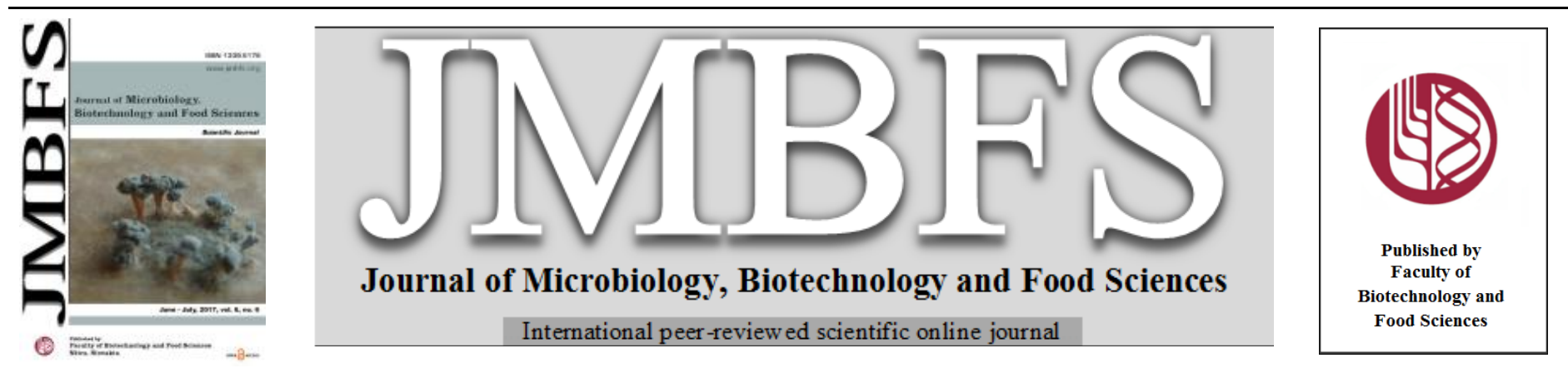

\title{
ANTIMICROBIAL ACTIVITY OF MARINE MICROALGAE ISOLATED FROM MOROCCAN COASTLINES
}

\author{
Amal Maadane ${ }^{1,2}$, Nawal Merghoub $^{1, *}$, Najib El Mernissi ${ }^{1}$, Tarik Ainane ${ }^{1}$, Saaïd Amzazi ${ }^{2}$, Imane Wahby ${ }^{l,}$, Youssef Bakri $^{2}$
}

Address(es):

${ }^{1}$ Green Biotechnology Center. Moroccan Foundation for Advanced Science, Innovation \& Research (MAScIR) - Rabat Design Center, Mohamed Al Jazouli StreetMadinat AlIrfane- 10100 Rabat -Morocco.

${ }^{2}$ Laboratory of Biochemistry-Immunology. Faculty of Sciences, Mohammed V University, Ibn Battouta Avenue, B.P. 1014 RP, Rabat. Morocco.

*Corresponding author: mailto:merghoubn@yahoo.fr / n.merghoub@ mascir.com

doi: $10.15414 /$ jmbfs.2017.6.6.1257-1260

\section{ARTICLE INFO}

Received 15.9. 2015

Revised 22.3. 2017

Accepted 14. 4. 2017

Published 1. 6. 2017

Regular article OPEN $\partial_{\text {ACCESS }}$

\begin{abstract}
The present investigation aimed to study antimicrobial activities in marine microalgae, screened from Moroccan coastlines. Ethanolic extracts were prepared from the microalgae and evaluated each against the bacteria: Escherichia coli, Pseudomonas aeruginosa and Staphylococcus aureus, the yeast Candida albicans and the fungus Aspergillus niger. The highest antibacterial activity was found in the extract of Tetraselmis sp. which exhibited an inhibitory effect against the three bacteria with a MIC of 2.6 to $3.0 \mathrm{mg}$ extract per mL culture. Extracts from the other microalgae: Dunaliella Salina, Nannochloropsis gaditana, Dunaliella sp., Phaeodactylum tricornutum and Isochrisis sp. each showed inhibitory activity against $E$. coli or $P$. aeruginosa with a MIC of 2.6 to $4.3 \mathrm{mg}$ extract per $\mathrm{mL}$. The extract of $N$. gaditana also inhibited S. aureus growth. However, the extracts from the microalgae, Chaetoceros sp. and Chlorella sp. showed no effect under the applied experimental conditions. All the tested extracts inhibited the growth of $C$. albicans; the highest activity was obtained from $N$. gaditana with a MIC of $4.0 \mathrm{mg}$ extract per $\mathrm{mL}$ culture. Aspergillus niger appeared to be resistant to the effect of the extracts. The observed antimicrobial activities were linked to the contents of the extracts in fatty acids, carotenoids and phenolic compounds. In conclusion, the studied microalgae could be considered as a potential natural source of bioactive compounds with antimicrobial activities.
\end{abstract}

Keywords: Marine microalgae, antimicrobial activity, phenolic content, carotenoids, fatty acids

\section{INTRODUCTION}

There has been increasing demand for new antimicrobial compounds in response to continuous evolution of microbial pathogens in antibiotic-resistance. Marine environment has been considered among the most promising sources of antimicrobial compounds, as numerous sea organisms produce bioactive metabolites in response to environmental stress and develop chemical strategy for defense and survival (Mhadhebi et al., 2012). A large number of new active antimicrobial compounds have been isolated from marine sources. But, the majority of these compounds has not been yet characterized (Sanmukh et al., 2014).

Marine microalgae constitute attractive sources of novel and active metabolites, comprising proteins, enzymes, pigments and polyunsaturated fatty acids (PUFA) that could be exploited in pharmaceutical, food, feed and cosmetic industries (Mendes et al., 2003; Cardozo et al., 2007; Surendhiran et al., 2014) Compounds with pharmaceutical characteristics, as antioxidative, antiinflammatory, antimicrobial or antitumoral properties, have been identified; some of them have been in the clinical trial state (Guedes et al., 2011; Kwak et al., 2014). Antimicrobial activities are among the most researched features in natural extracts. They have been attributed to different compounds, including, indoles, terpene derivatives, acetogenins, phenols, fatty acids and hydrocarbons (Bhakuni and Rawat, 2005; Santoyo et al., 2009).

Selected examples from the studied antimicrobial activities in microalgae are summarized in Table 1. However, to our knowledge, there are no data available on the antimicrobial potential of microalgae, isolated from the Moroccan coastlines. In order to evaluate this potential, nine microalgae, collected from these coastlines and identified, were extracted with ethanol; the collected extracts were examined against microbial targets. The obtained results are described hereafter, and discussed with consideration to the previously determined contents of the microalgal extracts in fatty acids, carotenoids and phenolic compounds (Maadane et al., 2015).

Table 1 Extracts and compounds from microalgae with antimicrobial activity

\begin{tabular}{|c|c|c|c|}
\hline Microalgal species & Active extracts/compounds & Target microorganisms & References \\
\hline Phaeodactylum tricornutum & Eicosapentaenoic acid & $\begin{array}{c}\text { Listonella anguillarum } \\
\text { Lactococcus garvieae } \\
\text { Staphylococcus aureus } \\
\text { Vibrio } \mathrm{sp} . \\
\end{array}$ & $\begin{array}{l}\text { (Desbois } \text { et al., 2009) } \\
\text { (Smith } \text { et al., 2010) }\end{array}$ \\
\hline Dunaliella salina & Faty acids & $\begin{array}{c}\text { Staphylococcus aureus } \\
\text { Candida albicans } \\
\end{array}$ & (Herrero et al., 2006) \\
\hline Haematococcus pluvialis & $\begin{array}{l}\text { Short chain fatty acids (butanoic } \\
\text { acid, methyl lactate) }\end{array}$ & $\begin{array}{c}\text { Escherichia coli } \\
\text { Staphylococcus aureus Candida } \\
\text { albicans } \\
\end{array}$ & (Santoyo et al., 2009) \\
\hline Chloroccum humicola & Pigments & $\begin{array}{c}\text { E. coli } \\
\text { Staphylococcus aureus } \\
\text { Bacillus subtilis } \\
\text { Streptococcus } \mathrm{sp} . \\
\text { Bacilus } \mathrm{sp} . \\
\text { Pseudomonas } \mathrm{sp} .\end{array}$ & $\begin{array}{l}\text { (Bhagavathy et al., 2011) } \\
\text { (Muthulakshmi et al., 2012) }\end{array}$ \\
\hline
\end{tabular}




\begin{tabular}{|c|c|c|c|}
\hline & & $\begin{array}{c}\text { Staphylococcus sp. } \\
\text { E. coli } \\
\end{array}$ & \\
\hline $\begin{array}{l}\text { Anabena sphaerica } \\
\text { Oscillatori alimentica } \\
\text { Spirulina platensis }\end{array}$ & Polyphenols & $\begin{array}{c}\text { E. coli } \\
\text { Staphylococcus aureus }\end{array}$ & $\begin{array}{l}\text { (Klejdus } \text { et al., 2010) } \\
\text { (Hetta } \text { et al., 2014) }\end{array}$ \\
\hline Pithophora oedogonium & Ethanolic extract & $\begin{array}{c}\text { Salmonella } \\
\text { Staphylococcus sp. }\end{array}$ & (Danyal et al., 2013) \\
\hline Tetraselmis suecica & Fatty acids & $\begin{array}{c}\text { Vibrio cholerae, } \\
\text { Klebsiella pneumoniae, Escherichia } \\
\text { coli, Pseudomonas aeruginosa, } \\
\text { Salmonella } \mathrm{sp} . \\
\text { Proteus } \mathrm{sp} . \\
\text { Streptococcus pyogens, } \\
\text { Staphylococcus aureus, Bacillus } \\
\text { megaterium } \\
\text { Bacillus subtilis }\end{array}$ & $\begin{array}{l}\text { (Dooslin Mercy Bai and } \\
\text { Krishnakumar, 2013) }\end{array}$ \\
\hline
\end{tabular}

\section{MATERIALS AND METHODS}

\section{Microalgae and culture conditions}

Nine marine microalgae were selected for this study from the collection of Moroccan Foundation for Advanced Science, Innovation \& Research (MAScIR, Rabat). They were identified (Maadane et al., 2015) as: Nannochloropsis gaditana, Dunaliella salina, Dunaliella sp., Phaedactylum tricornutum, Isochrysis sp., Navicula sp., Chaeotoceros sp., Chlorella sp. and Tetraselmis sp. Culturing conditions of the microalgae were previously described (Maadane $\boldsymbol{e}$ al., 2015). Briefly, batch cultures were realized in $5 \mathrm{~L}$ flasks containing sterile natural seawater, enriched with F/2 medium nutrients; the cultures were agitated by air bubbling at $25{ }^{\circ} \mathrm{C}$, under continuous illumination at intensity of 150 $\mu \mathrm{mol} . \mathrm{m}^{-2} \cdot \mathrm{sec}^{-1}$; microalgal biomasses were harvested by centrifugation, freezedried and stored at $-20^{\circ}$ until use.

\section{Extraction of microalgal substances}

Crude extracts from the microalgae were prepared by extracting $1 \mathrm{~g}$ of dried biomass with $100 \mathrm{ml}$ of ethanol for $3 \mathrm{~h}$ at room temperature, in the darkness. The extraction was repeated twice for each alga; collected extracts were combined into one sample. The samples were then filtered and concentrated under reduced pressure in a rotary evaporator. The resulting concentrated extracts were stored at $-20^{\circ} \mathrm{C}$ until use.

\section{Extract antimicrobial activity evaluation}

The microalgal extracts were tested against five microorganisms, including two Gram-negative bacteria: Escherichia coli (ATCC-8739), Pseudomonas aeruginosa (ATCC-9027), one Gram-positive bacterium, Staphylococcus aureus (ATCC-6538), the yeast Candida albicans (ATCC-10231) and the mold Aspergillus niger (ATCC-16404). Spores of the mold were harvested into sterile distilled water from monoconidial cultures, developed on potato dextrose at $24^{\circ} \mathrm{C}$ during 7 days

The minimum inhibitory concentrations (MICs) of the extracts were determined against all the tested microorganisms using the broth microdilution method (Scorzoni et al., 2007). Microbial samples were prepared by dilution with growth media to obtain inocula at $10^{5}$ colony forming units (CFU) per $\mathrm{mL}$ culture. The test cultures were performed in Muller Hinton broth for bacteria, or in Sabouraud dextrose broth for $C$. albicans or A. Niger. The culturing media were supplemented with $0.5 \%$ Tween-20. Samples of the extracts were prepared by different dilutions in DMSO, and tested at a final concentration ranging from 0.5 to $5 \mathrm{mg}$ extract per $\mathrm{mL}$ culture. Microbial growth was allowed in 96-well microtitration plates by dispensing into each well $180 \mu \mathrm{L}$ of microbial culture and 20 $\mu \mathrm{L}$ of microalgal extract sample at various concentrations. The final DMSO amount, being less than $4 \%$, was without growth inhibition effect. Sample blanks were prepared for all the extracts by adding $20 \mu \mathrm{L}$ of each extract sample to 180 $\mu \mathrm{L}$ of Mueller Hinton (or Sabouraud dextrose) broth medium. The plates were incubated at $37^{\circ} \mathrm{C}, 24 \mathrm{~h}$ for the bacteria and $48 \mathrm{~h}$ for C. albicans or A. niger. The antibiotics, chloramphenicol and amphotericin B were used as positive controls against the bacteria or C. albicans and A. niger, respectively. The viability of the examined microorganisms was assessed by measuring absorbance of cultures at $600 \mathrm{~nm}$ against the Mueller Hinton or the Sabouraud dextrose broth, using a Multiscan Spectrophotometer (Thermo-Fisher Scientific Inc). Assays were carried out in triplicate, and repeated twice. Microbial growth inhibition was expressed in percentage term according to the equation:

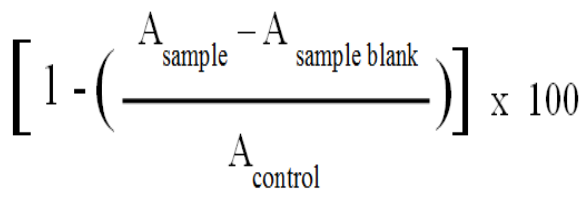

$\mathrm{A}_{\text {control: }}$ absorbance of the cullture control; $\mathrm{A}_{\text {sample: }}$ absorbance of the culture test sample; $\mathrm{A}_{\text {sample blank: }}$ absorbance of the extract sample in the nutrient broth.

\section{RESULTS AND DISCUSSION}

The antimicrobial activity level in the ethanolic extracts of the examined microalgae varied depending on the targeted microorganism and the microalgal strain (Table 2). The extract of Tetraselmis sp. exhibited an antimicrobial activity against both Gram-positive and Gram-negative bacteria with the lowest MIC values, ranging from 2.6 to $3.0 \mathrm{mg}$ per $\mathrm{mL}$ culture. Meanwhile, the ethanolic extract from Dunaliella salina showed an antibacterial activity against only the Gram-negative bacteria, E. coli and $P$. aeruginosa. However, the extracts from $N$. gaditana, Dunaliella sp. P. tricornutum, and Isochrysis sp. showed relatively moderate antibacterial activities at the used extract concentrations. Chlorella sp. and Chaetoceros sp. did not exhibit any inhibitory activity against the tested bacteria, even at the concentration of $5.0 \mathrm{mg}$ extract per $\mathrm{mL}$.

Table 2 Antimicrobial activities of ethanolic extracts of microalgae, isolated from Moroccan coastlines.

MIC values are presented as means $\pm \mathrm{SD}(\mathrm{n}=6)$. The antimicrobial activity was determined in a culture assay of $0.2 \mathrm{~mL}$, composed of $0.18 \mathrm{~mL}$ medium and $0.02 \mathrm{~mL}$ extract sample.

\begin{tabular}{|c|c|c|c|c|c|}
\hline \multirow{2}{*}{ Microalgae } & \multicolumn{5}{|c|}{ MIC (mg extract per mL culture) } \\
\hline & E.coli & P. aeruginosa & S. aureus & C. albicans & A. niger \\
\hline Tetraselmis sp. & $2.6 \pm 0.2$ & $2.9 \pm 0.9$ & $3 \pm 0.1$ & $>5$ & - \\
\hline Dunaliella Salina & $3.4 \pm 0.4$ & $2.6 \pm 0.8$ & - & $>5$ & - \\
\hline Nannochloropsis gaditana & $3.4 \pm 0.2$ & $>5$ & $4.5 \pm 0.6$ & $4.0 \pm 0.6$ & - \\
\hline Chlorella sp. & - & - & - & $>5$ & - \\
\hline Dunaliella sp. & $>5$ & $4.3 \pm 0.1$ & $>5$ & $>5$ & - \\
\hline Navicula sp. & $>5$ & $>5$ & $>5$ & $>5$ & - \\
\hline Phaeodactylum tricornutum & $4.3 \pm 0.1$ & $>5$ & $>5$ & $4.7 \pm 0.1$ & - \\
\hline Chaetoceros sp. & - & - & - & $>5$ & - \\
\hline Isochrisis sp. & $3.5 \pm 0.2$ & $>5$ & - & $>5$ & - \\
\hline
\end{tabular}

$>5$ : MIC is expected to be higher than $5 \mathrm{mg}$ extract per $\mathrm{mL}$ culture. -: absence of antimicrobial effect at the highest examined extract concentration, $5 \mathrm{mg}$ per $\mathrm{mL}$ culture. 
Only, $N$. gaditana and $P$. tricornutum showed an activity against $C$. albicans (Table 2). Extracts of the other microalgae had weak activity against this yeast, as at the maximal concentration used in the test, being $5.0 \mathrm{mg}$ per $\mathrm{mL}$ culture, the growth inhibition was less than $50 \%$. Therefore, the MICs of these extracts against $C$. albicans were expected to be higher than this concentration Paradoxically, no antifungal activity was observed in all the extracts against $A$ niger at the tested concentrations.

As noticed under the applied culture conditions, the MICs of the positive controls are in mean values: $0.085,0.145$ and $0.571 \mathrm{mg}$ chloramphenicol per mL culture for respectively $S$. aureus, $E$. coli and $P$. aeruginosa. The MIC of amphotericin against $C$. albicans was much higher, being $1.6 \mathrm{mg}$ per $\mathrm{mL}$ culture. For the microalgae that exhibited antimicrobial activities, the registered MICs, which were of 2.6 to $4.7 \mathrm{mg}$ extract per $\mathrm{mL}$ (Table 2) are by comparison to those of the antibiotics higher. However, they might be pharmaceutically significant, if the crude state of the tested extracts was considered, as these extracts contained different substances, and only some of them had inhibitory effect. The registered data were in fact concordant with literature-published observations, concerned with the antimicrobial activities of microalgal extracts, as those of Chaetoceros mulleri (Mendiola et al., 2007), Chlorella vulgaris (Plaza et al., 2012) and Nostoc sp. (Salem et al., 2014).

The antimicrobial activities described above could be attributed to different compounds, comprising those previously determined (Maadane et al., 2015) fatty acids, carotenoids and phenolic compounds. Fatty acids, which constitute major parts of the extracted biomasses, are particularly considered because their antimicrobial effects have been long recognized (e.g., Galbraith $\boldsymbol{e t}$ al., 1971; Desbois et al., 2009; Cakmak et al., 2014).

The extract from Tetraselmis sp. contains high amounts of oleic acid (cis-9octadecenoic acid) (48.8\% of the ethanol-extracted fatty acids), linoleic acid (cis cis-9,12-octadecadienoic acid) $(36.4 \%)$ and palmitic acid (hexadecanoic acid) $(18.6 \%)$. These fatty acids were determined as major components in the ethanolic-extract or hexanic-extract of Dunaliella salina (Herrero et al., 2006), and reported to be responsible, in a main part, of the antimicrobial activity, exercised against $E$. coli, $S$. aureus, and $C$. albicans. Besides, the antibacteria activities observed in the algal species, Nostoc spongiforme, Oscillatoria teniu and Chlorococcus sp. were linked to their contents in fatty acids (Suresh $\boldsymbol{e t}$ al. 2014). Considering these literature-data, the antibacterial activity of Tetraselmis sp. (Table 2) can be linked, for a major part, to its content in palmitic, oleic and linoleic acids.

The analysis of the ethanolic extract from $D$. salina showed that this microalga contains the highest amount of ethanol extractable PUFA, being $76.9 \%$ of which linolenic acid (all-cis-9,12,15-octadecatrienoic acid) constitutes a high part (45.3\%) (Maadane et al., 2015). According to Lee et al. (2002), the antimicrobial activity of linolenic acid was high against Gram-positive bacteria, but low against Gram-negative bacteria. The ethanolic extract of $D$. salina (Table 2 ) showed antibacterial activity against the Gram-negative bacteria, $E$. coli and $P$. aeruginosa and no activity against the Gram-positive bacterium $S$. aureus. If this activity was mainly attributed to the linolenic acid which was found to be abundant in the tested extract, then our observations regarding $S$. aureus are in contrast to those by Lee et al. (2002).

The extract from $N$. gaditana was shown to contain important amounts of palmitoleic acid (cis-9-hexadecenoic acid) (28\%), palmitic acid $(24.1 \%)$, oleic acid $(15.3 \%)$ and eicosapentaenoic acid (14\%). Also, P. tricornutum extract was shown to be rich in these acids. Their antimicrobial activities against bacteria and C. albicans (Table 2) might be due for a great part to these dominant fatty acids, in agreement with published observations (Surendhiran et al., 2014), concerned with the antibacterial activity of the $\mathrm{C} 16-\mathrm{C} 20$ fatty acids-rich extract from $N$ oculata. Especially, eicosapentaenoic acid, dominant in extracts of $P$. tricornutum must have considerable antimicrobial effect (Desbois et al., 2009).

Astaxanthin, a carotenoid pigment, was demonstrated to have a significant effect against both Gram-negative and Gram-positive bacteria (Ushakumari and Ramanujam, 2013). Besides, different extracted carotenoids from microalgae, comprising D. salina (Herrero et al., 2006) and Chlorococcum humicola (Bhagavathy et al., 2011) have been reported to possess important antimicrobial activities, effecting Gram-positive and Gram-negative bacteria and C. albicans. According to our previous data (Maadane et al., 2015), only the ethanolic extracts from Dunaliella sp., P. tricornutum and Tetraselmis sp. contained carotenoids at significant amounts, being 10.8, 6.3, and $4.6 \mathrm{mg}$ per g extract, respectively. Consequently, the observed antimicrobial activities of these extracts could be due not only to their fatty acids, but also to their carotenoids, in concordance with the referenced data. Besides, the ethanol extracts from $N$. gaditana, Tetraselmis sp. and P. tricornutum contained high content of phenolic compounds (polyphenols), being 32, 25.5 and16.8 mg, expressed in gallic acid equivalent per $\mathrm{g}$ extracted biomass, respectively. These extracts exhibited the highest antimicrobial activity (Table 2) which could be attributed, for a part, to their phenolic compounds in agreement with published observations (e.g., Pane et al., 2015).

Bioactive compounds released by microalgal cells are either bactericidal or bacteriostatic (Falaise et al., 2016). Their action mechanisms are still poorly understood. However, action modes have been suggested for growth inhibition or killing of bacteria by some of the functional molecules (Shannon and Abu-
Ghannam, 2016). In this, phytochemicals, comprising microalgal substances, may act by inducing cellular membrane perturbations, interference with certain microbial metabolic processes, modulation of signal transduction or gene expression. Free fatty acids could initiate peroxidative processes, and preclude the synthesis of bacterial fatty acids (Zheng $\boldsymbol{e t}$ al., 2005; Desbois and Smith 2010). Besides, free fatty acids might interact with cellular membranes of microbial cells, causing leakage of molecules from these cells, reduction of their nutrient uptake or inhibition of their respiration (Suresh et al., 2014).

In the present study the antimicrobial activities of the studied microalgal extracts were attributed to their contents of fatty acids, carotenoids and polyphenols, as discussed above. These substances probably act together, either in an independent or synergistic manner. Whatever their action mode, the data, described here demonstrated the presence of pharmaceutically promising antibacterial compounds in the screened microalgae from the Moroccan costlines.

Acknowledgments: The present study is a part of the authors' project, aimed at the investigation of the pharmaceutical potential of Moroccan costlines-screened microalgae. This project has been funded by the Moroccan Foundation for Advanced Science Innovation and Research (MAScIR). The authors are grateful to the MAScIR for this funding.

\section{REFERENCES}

Bhagavathy, S., Sumathi, P., \& Jancy Sherene Bell, I. (2011). Green algae Chlorococcum humicola- a new source of bioactive compounds with antimicrobial activity. Asian Pacific Journal of Tropical Biomedicine, S1-S7. http://dx.doi.org/10.1016/s2221-1691(11)60111-1.

Bhakuni, D.S., \& Rawat, D.S. (2005). Bioactive Marine Natural products (ISBN 1-4020-3484-9 e-book). Co-published: New York: Springer, New Delhi: Anamaya.

Cakmak, Y.S., Kaya, M., \& Asan-Ozusaglam, M. (2014). Biochemical composition and bioactivity screening of various extracts from Dunaliella salina, a green microalga. EXCLI Journal, 13, 679-690.

Cardozo, K. H. M., Guaratini, T., Barros, M. P., Falcão, V. R., Tonon, A. P., Lopes, N. P., Campos, S., Torres, M. A., Souza, A. O., Colepicolo, P. (2007). Metabolites from algae with economical impact. Comparative Biochemistry and Physiology Part C: Toxicology \& Pharmacology. 146, 60-78. http://dx.doi.org/10.1016/j.cbpc.2006.05.007.

Danyal, A., Mubeen, U., \& Malik, K.A. (2013). Investigating two native alga species to determine antibiotic susceptibility against some pathogens. Current Research Journal of Biological Sciences, 5 (2), 70-74.

Desbois, A.P., Mearns-Spragg, A., \& Smith, V.J. (2009). A fatty acid from the diatom Phaeodactylum tricornutum is antibacterial against diverse bacteria including multi-resistant Staphylococcus aureus (MRSA). Marine Biotechnology, 11, 45-52. http://dx.doi.org/10.1007/s10126-008-9118-5.

Desbois, A.P., \& Smith, V.J. (2010). Antibacterial free fatty acids: activities, mechanisms of action and biotechnological potential. Applied Microbiology and Biotechnology, 85, 1629-1642. DOI: 10.1007/s00253-009-2355-3.

Dooslin Mercy Bai, V., \& Krishnakumar, S. (2013). Evaluation of antimicrobial metabolites from marine microalga Tetraselmis suecica using gas chromatography-mass spectrometry (GC-MS) analysis. International Journal of Pharmacy and pharmaceutical Sciences, 5, 17-23.

Falaise, C., François, C., Travers, M.A., Morga, B., Haure, J., Tremblay, R., Turcotte, F., Pasetto, P., Gastineau, R., Hardivillier, Y., Leignel, V., \& Mouget, J.L. (2016). Antimicrobial compounds from eukaryotic microalgae agains human pathogens and diseases in aquaculture. Marine Drugs, 14(9), 159 doi:10.3390/md14090159.

Galbraith, H., Miller, T.B., Paton, A.M., \& Thompson, J.K. (1971). Antibacteria activity of long chain fatty acids and the reversal with calcium, magnesium, ergocalciferol and cholesterol. Journal of Applied Microbiology, 34, 803-813. http://dx.doi.org/10.1111/j.1365-2672.1971.tb01019.x.

Guedes, A. C., Amaro, H. M. \& Malcata, F. X. (2011). Microalgae as sources of carotenoids. Marine Drugs, 9, 625-644. http://dx.doi.org/10.3390/md9040625. Herrero, M., Ibañez, E., Cifuentes, A., Reglero, G., \& Santoyo, S. (2006). Dunaliella salina microalga pressurized liquid extracts as potential antimicrobials. Journal of Food Protection, 69, 2471-2477.

Hetta, M., Mahmoud, R., El-Senousy, W., Ibrahim M., El-Taweel G., \& Ali G. (2014). Antiviral and antimicrobial activity of spirulina platensis. World Journal of Pharmacy and Pharmaceutical Sciences, 3, 31-39.

Klejdus, B., Lojková, L., Plaza, M., Snóblová, M., \& Stérbová D. (2010) Hyphenated technique for extraction and determination of isoflavones in algae: Ultrasound-assisted supercritical fluid extraction followed by fast chromatography with tandem mass spectrometry. Journal of Chromatography A, 1217 (51), 7956-7965. http://dx.doi.org/10.1016/j.chroma.2010.07.020.

Kwak, H. W., Kang, M. J., Bae, J. H., Hur, S. B., Kim, I-S., Park, Y. H. \& Lee, K. H. (2014). Fabrication of Phaeodactylum tricornutum extract-loaded gelatin nano fibrous mats exhibiting antimicrobial activity. International Journal of
Biological
Macromolecules,
63 ,
198-204. 
Lee, J-Y., Kim, Y-S., \& Shin, D-H. (2002). Antimicrobial synergistic effect of linolenic acid and monoglyceride against Bacillus cereus and Staphylococcus aureus. Journal of Agricultural and Food Chemistry, 50, 2193-2199.

Maadane, A., Merghoub, N., Ainane, T., El Arroussi, H., Benhima, R., Amzazi, S., Bakri, Y., \& Wahby, I. (2015). Antioxidant activity of some Moroccan marine microalgae: pufa profiles, carotenoids and phenolic content. Journal of Biotechnology, 215, 13-19. http://dx.doi.org/10.1016/j.jbiotec.2015.06.400.

Mendes, R.L., Nobre, B.P., Cardoso, M.T., Pereira, A.P., \& Palabra, A.F. (2003) Supercritical carbon dioxide extraction of compounds with pharmaceutical importance from microalgae. Inorganica Chimica Acta. 356, 328-334. http://dx.doi.org/10.1016/S0020-1693(03)00363-3.

Mendiola, J. A., Torres, C.F., Toré, A., Martin-Alvarez, P. J., Santoyo, S., Arredondo, B. O., Señoráns, F. J., Cifuentes, A., \& Ibáñez, E. (2007). Use of supercritical $\mathrm{CO}_{2}$ to obtain extracts with antimicrobial activity from Chaetoceros mulleri microalga. A correlation with their lipidic content. European Food Research and Technology, 224, 505-510. http://dx.doi.org/10.1007/s00217006-0353-6.

Mhadhebi, L., Chaieb, K. \& Bouraoui, A. (2012). Evaluation of antimicrobial activity of organic fractions of six marine algae from Tunisian Mediterranean coasts. International Journal of Pharmacy \& Pharmaceutical Sciences, 4 (1), 534-537.

Muthulakshmi, M., Saranya, M., \& Selvakumar, G. (2012). Extraction, partial purification and antibacterial activity of phycocyanin from Spirulina isolated from fresh water body against various human pathogens. Journal of Algal biomass Utilization, 3 (3), 7-11.

Pane, G., Cacciola, G., Giacco, E., Mariottini, G. L., \& Coppo E. (2015) Assessment of the antimicrobial activity of algae extracts on bacteria responsible of external otitis. Marine Drugs, 13, 6440-6452. doi:10.3390/md13106440.

Plaza, M., Santoyo, S., Jaime, L., Avalo, B., Cifuentes, A., Reglero, G., Reina, G. G. B., Señoráns, F. J., \& Ibáñez, E. (2012). Comprehensive characterization of the functional activities of pressurized liquid and ultrasound-assisted extracts from Chlorella vulgaris. LWT Food Science and Technology, 46, 245-253. http://dx.doi.org/10.1016/j.lwt.2011.09.024.

Salem, O. M. A, Hoballah, E. M., Ghaz, S. M., \& Hanna S.N. (2014). Antimicrobial activity of microalgal extracts with special emphasize on Nostoc sp. Life Science Journal, 11(12), 752-758.

Santoyo, S., Rodriguez-Meizoso, I., Cifuents, A., Jaime, L., Garcia-Blairsy, Reina G., Senoraňans, F.J., \& Ibaňe E. (2009). Green Processes based on the extraction with pressurized fluids to obtain potent antimicrobials from Heamatococcus pluvialis microalgae. LWT Food Science and Technology, 42, 1213-1218. http://dx.doi.org/10.1016/j.lwt.2009.01.012.

Sanmukh, S., Bruno, B., Ramakrishnan, U., Khairnar, K., Swaminathan, S., \& Paunikar, W. (2014). Bioactive compounds derived from microalgae showing antimicrobial activities. Journal of Aquaculture Research and Development. 5 (3), 224 http://dx.doi.org/10.4172/2155-9546.1000224.

Scorzoni, L., Benaducci, T., Almeida, A. M. F., Silva, D. H. S., Bolzani, V. S., \& Mendes-Giannini, M. J. S. (2007). Comparative study of disk diffusion and microdilution methods for evaluation of antifungal activity of natural compounds against medical yeasts Candida spp. and Cryptococcus sp. Revisita de Ciências Farmcêutica Básica e Aplicada, 28 (1), 25-34.

Shannon, E., \& Abu-Ghannam, N. (2016). Antibacterial derivatives of marine algae: an overview of pharmacological mechanisms and applications. Marine Drugs, 14, 81. doi:10.3390/md14040081.

Smith, V.J., Desbois, AP, \& Dyrynda, E.A. (2010). Conventional and unconventional antimicrobials from fish, marine invertebrates and microalgae. Marine Drugs, 8, 1213-1262. doi:10.3390/md8041213.

Surendhiran, D., Vijay, M., Sirajunnisa, A.B., Subramaniyan, T. \& Shanthalin, A. (2014). A green synthesis of antimicrobial compounds from marine microalgae Nannochlorpsis oculata. Journal of coastal life medicine, 2 (11), 859-863. doi: 10.12980/jclm.2.2014apjtb-2014-0138.

Suresh, A., Praveenkumar, R., Thangaraj, R., Oscar, F.L., Baldev, E., Dhanasekaran, D., \& Thajuddin, N. (2014). Microalgal fatty acid methyl ester a new source of bioactive compounds with antimicrobial activity. Asian Pacific Journal of Tropical Disease. doi: 10.1016/S2222-1808(14)60769-6.

Ushakumari, U. N., \& Ramanujan, R. (2013). Isolation of astaxanthin from marine yeast and study of its pharmacological activity. International Current $\begin{array}{lllll}\text { Pharmaceutical } & \text { Journal, } & 2 & \text { (3), } & \text { 67-69. }\end{array}$ http://dx.doi.org/10.3329/icpi.v2i3.13584

Zheng, C. J., Yoo, J. S., Lee, T. G., Cho, H. Y., Kim, Y. H., \& Kim, W. G. (2005). Fatty acid synthesis is a target for antibacterial activity of unsaturated fatty acids. FEBS Letters, 579 (23), 5157-5162. DOI: 10.1016/j.febslet.2005.08.028 